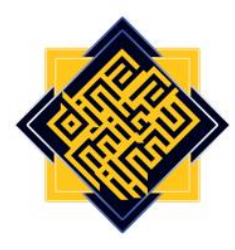

\title{
Examining Teaching Materials in Higher Education Against Religious Intolerance and Pluralism in the Global Era: Islamic Perspective
}

\author{
Sitti Jamilah \\ State Islamic Institute (IAIN) of Parepare \\ Jl. Amal Bakti No. 8 Soreang, Parepare, Indonesia \\ e-mail:stjamilahamin@iainpare.ac.id
}

Abstract

This study aims to investigate the role of the study of teaching materials in universities on religious intolerance and pluralism. The study also explores the Islamic perspective on these two dimensions. The location of the research was carried out at the IAIN Parepare of South Sulawesi Province, Indonesia. The source of research data is secondary data obtained from document review of teaching materials in the Aqidah Akhlak (moral theology) course as well as literature relevant to the research topic. The literature study research methodology guided by content analysis focuses on three topics, namely teaching materials, religious intolerance, and pluralism in the view of Islam. The study revealed two findings. First, the results of a study of the components or the appropriateness of the contents of the items of teaching materials in accordance with the values of tolerance as contained in Pancasila and Bhineka Tunggal Ika. Thus, these teaching materials contribute to preventing religious intolerance and provide a new perspective on pluralism. Second, in the view of Islam, it is known that religious intolerance can be avoided by tasamuh, namely by instilling a commendable moral attitude. While pluralism there are two opposing schools between those who accept and reject. In the Qur'an, there is an explanation of pluralism as a necessity, human diversity in togetherness. The conclusion is that the study of teaching materials contributes to supporting tasamuh behavior and avoiding negative views about pluralism. Pluralism is not recommended, namely religious pluralism which is feared to have a negative impact on aqidah. With the study of teaching materials, negative possibilities can be minimized as long as they are in accordance with practice. 


\section{Sitti Jamilah}

Because after all, the values of pluralism are also able to foster mutual respect and appreciation between fellow human beings so that they can support the development of student morality. The expected implication is that universities must supervise and provide input on teaching materials that have the potential for the concepts of tolerance and pluralism. The government needs to support the socialization of the true importance of tolerance and pluralism in the campus environment.

Keywords: Intolerance, Pluralism, Teaching materials

\section{A. Introduction}

The era of globalization as a fact that modern society is complex is facing serious challenges related to issues of intolerance, pluralism, and conflict in various parts of the world. In addition, the process of democracy and liberalization as well as political issues have an impact on the growth of pluralism and intolerance (Facal, 2020). For example, African countries face the problem of pluralism which is severe enough to cause ethnic tensions and conflicts between communities and governments (Badru, 2020). Likewise in Pakistan, where cases of religious intolerance have entered a fairly high level of severity which has a negative impact on the stability of the country (Suleman et al., 2018). This phenomenon makes universities receive sharp attention from the world community. This is associated with various cases of terrorism, and radicalization targeting students and graduates from universities (Mahfud et al., 2018). One study found that the cause of the severity of intolerance may be due to the impact of the educational curriculum namely a lack of knowledge about the diversity of society; the impact of hate literature, lack of social justice, family background, and environmental pressures; the impact of information media as well as the influence of external forces. This study assesses the educational curriculum as the main reason behind religious intolerance. This shows the need to investigate educational institutions as a factor that can reduce religious intolerance in countries prone to religious conflict (Khan et al., 2017).

Indonesia as an archipelagic country and diversity and has many universities is an inseparable part of various issues of intolerance and pluralism. The literature states that religious freedom in Indonesia is increasingly fragile. Even cases of religious intolerance in 2019-2020 rose significantly, especially in the provinces of East Java and West Java. In 2020 there were 180 cases of intolerance with 422 acts, this number increased from 2019 with 327 acts of violation of freedom of religion or belief (KBB) (CNN Indonesia, 2021). Several recent studies have begun to highlight strategic efforts that can be made to minimize cases of intolerance and support the creation of a plural society (multicultural). Although, in Indonesia, the understanding of religious pluralism is prohibited by the Indonesian Ulema Council (MUI) because of its negative impact on the creed of Muslims. Intolerance has triggered many mass demonstrations that have led to violent and anarchic acts (Mietzner \& Muhtadi, 2019) such as Muslim and Christian conflicts in Maluku and Poso (Gustiana Kambo, 2021). This phenomenon is further exacerbated after the contemporary 
Reformation. The lack of attention from the government, educational institutions, and scientific researchers on the issue of intolerance and pluralism causes a very worrying negative impact because it is feared that in the long term it can cause division and change in the ideology of Indonesian society (Sebastian \& Arifianto, 2020).

Religious intolerance and pluralism are familiar in universities for various reasons. According to Hudson (2021), the main factors that influence shaping these behaviors are the student community, peer groups, and society. Other research shows that the negative influence of higher education culture does not support the learning and development of student competencies. As a result, minority students often experience religious and spiritual discriminatory experiences (Fosnacht \& Broderick, 2020). Universities are beginning to adopt a learning-based approach by promoting tolerance and pluralism. This is believed to be able to increase the capacity and willingness of students to manage differences more constructively. Previous literature offers a study of teaching materials as a way to provide knowledge about the importance of practicing religious tolerance in society. The findings explain that low tolerance education in higher education institutions can trigger intolerance (Muhid, 2020).

As a Muslim-majority country, it is necessary to provide an understanding of religious intolerance and pluralism. The teaching materials contained in the Multicultural Education and Islamic Religious Education courses can support tolerance and pluralism education in universities. Lecturers are also the most important factor in spreading knowledge about tolerance education (Sirozi \& Yenrizal, 2020). Lecturers make teaching materials that are in accordance with the context of tolerance education and are able to contribute to religious tolerance education (Ifechukwude \& Gibson, 2021; Alhashmi et al., 2020). Islam itself recognizes the term tasamuh to avoid religious intolerance in society (Yanti \& Witro, 2019).

The novelty of the research is shown by the Study of Teaching Materials in Higher Education on various issues of Religious Intolerance and Pluralism. Previous studies have revealed that the cause of the practice of intolerance is due to weak laws and policies (Neo, 2020). Meanwhile, in this study, the study of teaching materials and the perspective of Islamic law were investigated in relation to the issue of religious intolerance and pluralism in Indonesia. Researchers tend to present conflicting findings. Pluralism is said to be a necessity for the salvation of mankind because of the mechanism of supervision and the manifestation of God's grace that is abundant to mankind. Pluralism can also create a sense of mutual respect between communities so as to minimize the occurrence of social conflicts. Other studies prohibit pluralism because it can pose a threat to self-identity and change belief values. However, none of the studies have investigated its relationship with teaching materials in higher education and straightened out the true view of Islam about these two.

The formulation of the research problem covers three main topics, namely the study of teaching materials, religious intolerance, and pluralism in the view of Islam as explained in the background of the research problem based on previous literature studies and 


\section{Sitti Jamilah}

phenomena that occur in universities in Indonesia. Of the three topics, the formulation of the problem in this study is as follows:

1. What is the study of teaching materials in universities on religious intolerance and pluralism in the global era?

2. What is the Islamic view of religious intolerance and pluralism in higher education in the global era?

\section{B. Literature Review}

\section{Study Teaching Materials}

A study is an investigation or examination. While teaching materials are a set of materials or substances for learning activities that are arranged systematically with the aim of showing the complete figure of the competencies that will be mastered by students. Thus the study of teaching materials contains an examination of certain values and information, attitudes and actions as well as skills related to certain language subjects in order to achieve learning objectives (McGrath, 2013). To achieve effective learning objectives, these teaching materials must be designed as well as possible by preparing ideal teaching materials by optimizing student involvement and knowledge transfer based on needs (Cloonan \& Fingeret, 2020). Teaching materials serve as guidelines for teachers and students in the learning process and become a tool for evaluating the achievement of these learning outcomes. Sources of teaching materials can be in the form of textbooks, research reports, journals, experts in the field of study, professionals, curriculum books, the internet, audiovisual media, and the environment. The function of teaching materials consists of three kinds (Allwright, 1981), (1) the function of teaching materials for educators in order to save teaching time so that the learning process becomes more effective; (2) the function of teaching materials for students to assist in improving competence in accordance with the guidelines for teaching materials; (3) the function of teaching materials based on learning strategies used both individually and in groups. The literature mentions the importance of teaching materials in the scope of higher education to improve student competence and evaluation of learning in order to produce graduates who are able to compete globally (Harwood, 2005).

\section{Religious Intolerance}

Studies find that intolerance implies a lack of ability to deal with groups/individuals (such as other religions, tastes, or cultures) that are opposed or rejected. Religious intolerance can form Euroscepticism (the idea that integration weakens the nation-state and the desire to slow or stop integration within the European Union), in this case, social identity becomes a strong determinant of Euroscepticism (Hobolt et al., 2011). Intolerance itself has more to do with reactionary ideological influences and socio-political conditions in the country than with religious beliefs and practices. Studies suggest that intolerance can be triggered by undemocratic tendencies of the government, causing hostility and ethnic-religious tensions (Karpov \& Lisovskaya, 2008). This can be a threat to the stability of the government. Religious intolerance is a condition in society if a group specifically refuses or is reluctant to tolerate or lack tolerance for the practices of other religions, 
adherents of certain beliefs, or beliefs based on certain religions (Nussbaum, 2004). Religious intolerance can be avoided by instilling the values of religious moderation and religious spirit in educational institutions (Effendi, 2020).

\section{Pluralism}

Pluralism is not just diversity. Pluralism can be interpreted as an understanding that respects differences in society and allows these different groups to continue to carry out and maintain the cultural uniqueness of their group. Pluralism cannot be understood simply by saying that society is plural or merely as a negative virtue (Diana, 2006). Pluralism must be understood as the true affinity of diversity in the bonds of civilization. According to Thoha (2009), there are four characteristics of pluralism, namely secular humanism, global theology, syncretism, and perennial philosophy. These characteristics trigger opposite effects. The positive impact of pluralism is; (1) provide space for groups/individuals in determining their choices and life goals; (2) learn about maturity and mutual respect for diversity, and (3) maximize the potential of each group/individual. Meanwhile, from the negative side, namely; (1) vulnerable to social conflict because the granting of the right to freedom can blur the boundaries of decency; (2) the emergence of extreme and fanatical attitudes towards culture and religion; and (3) the emergence of ethnocentrism, namely underestimating other cultures and religions. Pluralism requires organizational and legal measures in order to secure and support equality and brotherhood (Shiekh, 2013). Pluralism is also able to push towards accommodation and maintenance of wealth and uniformity of welfare conceptually (Mitchell \& Alexandrova, 2021).

\section{Research Methodology}

Research design as a strategy chosen to comprehensively integrate research components logically and systematically according to the research focus. The focus of this research is to investigate the role of studying Aqidah Akhlak teaching materials in Higher Education towards religious intolerance and pluralism and to express Islamic views on these two topics. Teaching materials The Aqidah Morals course was chosen by the researcher because the components of the content were considered relevant to the research topic. The research uses a literature study approach, namely with sources and data collection obtained from literature, documentation, and scientific articles both with direct citations and indirect citations (Snyder, 2019). The content analysis proposed by Weber (1990) is used to guide research to answer the problem formulation and make relevant conclusions. The research location is at IAIN Pare-Pare College, South Sulawesi Province, Indonesia.

Data is a collection of information obtained through observation and searching for sources. The study obtained data from secondary data sources. Secondary data sources are data sources obtained indirectly through intermediary media. The research uses data sources derived from teaching materials for Aqidah Akhak courses and documentation obtained from teaching lecturer notes, digital information media for IAIN Pare-Pare College, and scientific articles that are in accordance with the research objectives. 


\section{Sitti Jamilah}

In the process of collecting data, the initial stage of the researcher conducts a literature study to determine the research topic and determine the formulation of the problem that is relevant to the background of the problem and research objectives. Then the researchers conducted a study of the teaching materials for Aqidah Akhlak courses by first asking for permission officially from the universities and lecturers concerned. After obtaining permission, then the researcher observed the teaching materials. The researcher also collected data from the lecturers' personal documents in the form of learning notes and evaluation assessments of teaching materials in the odd semester of the 2021 academic year, and scientific articles from reputable journals that are related to research. The main literature source years are taken from 2017-2021, except for the main theory. Researchers searched various reputable journals such as emerald, Taylor \& Francis, Scopus, and Sinta because they were considered to have qualified article standards. Assessment of teaching materials and journals has certain criteria. For teaching materials, the study was carried out by following the textbook guidelines in the Regulation of the Minister of Education and Culture of the Republic of Indonesia Number 3 of 2020 concerning National Standards for Higher Education and in accordance with the supervision of education in Indonesia, which consists of; competency standards, basic competencies, components or content feasibility, conformity of points, results of the study, as well as input and suggestions for improvement. While the assessment of scientific articles is abstract, research methods, findings, and implications.

Content analysis is a data analysis method that aims to describe the characteristics of the content and draw an important description of the characteristics of the content to draw inferences from the content. Content analysis is used by researchers as an effort to systematically identify the contents of the data that researchers have collected to answer the formulation of research problems as proposed by Weber (1990). The content analysis stage consists of five steps that can be used as needed, namely; (1) formulating the purpose of data analysis, in this study the purpose of data analysis is to reveal the relationship between the study of teaching materials on religious intolerance and pluralism and Islamic views; 2) conceptualization of the collected data and operationalizing the data; 3) make coding sheets based on predetermined categories that are arranged systematically so that there is no ambiguity in the categories. Categories provide about three main topics in research; 4) assessing accuracy or reliability, researchers use expert opinion in compiling categories that are associated with valid data; and 5) revising the coding rules to get the final result which is then taken with relevant conclusions and suggestions.

\section{Finding and Discussion}

1. Studying Teaching Materials in Higher Education Against Religious Intolerance and Pluralism in the Global Era

Research reveals the importance of studying teaching materials on religious intolerance and pluralism at IAIN Pare-Pare Higher Education. The results of the study 
revealed that the competency standards and basic competencies of the Aqidah Akhlak course contain learning values about avoiding intolerance and supporting pluralism.

Of the three competency standards consisting of; (1) basic understanding and purpose of Islamic aqidah; (2) increasing faith in Allah through understanding His attributes; and (3) applying commendable morals (tawadhu and tasamuh) to Allah SWT, all three of which fulfill the learning assessment of tolerance and pluralism in the sense of respecting human beings. Of the various basic competencies that are shown to students, they clearly hold the principles of Islamic teachings, namely faith, Islam, and Ihsan. Explaining the importance of tolerance, sincerity, obedience, and devotion and getting used to commendable behavior in everyday life.

Thus, it can be understood that conceptually, teaching materials in the Aqidah Akhlak course are able to support the avoidance of intolerance and support the discourse of pluralism in higher education which is expected to be practiced in social life. However, the shortcomings of teaching materials were identified from the absence of basic competencies regarding an in-depth understanding of the meaning of pluralism according to the Islamic view. Maybe this is because this course is intended as a lesson on commendable moral behavior, not focusing on multicultural learning. According to previous studies, there are different views on pluralism so that there is a debate until now, previous research found a prohibition on religious pluralism because it considers pluralism not in accordance with Islam and emphasizes the need for tolerance and harmony among communities (Basya, 2011). The views of the MUI fatwa contained in the MUI Fatwa decision No. 7/Munas VII/MUI/11/2005 dated July 29, 2005, stated that MUI forbids religious pluralism and forbids Muslims from adopting pluralism. Other studies differ and state that the vital contribution of neo-Modernist Islam refutes the notion that Islam is incompatible with pluralism (Barton et al., 2021). In developed countries such as France, the question is where religious pluralism is going because of the government regulation in the 2004 law regarding the prohibition of religious symbols seen in educational institutions (Barras, 2013). Kruja et al. (2021), support religious pluralism in educational institutions on the grounds of a multicultural society.

IAIN Pare-Pare College seems to have adopted a learning-based approach by promoting tolerance and pluralism as part of the goals of moderate Islamic colleges. This is believed to be able to increase the capacity and willingness of students to avoid intolerance, especially in the midst of the development and advancement of digitalization technology. The low level of tolerance education in higher education institutions can trigger an attitude of intolerance. Studying teaching materials is one way to provide knowledge about the importance of practicing religious tolerance (Muhid, 2020).

The role of lecturers in higher education is the spearhead of education. Therefore, teaching materials made by lecturers as guidelines in the learning process are very important to be arranged as well as possible. Teaching materials must be able to translate the correct values of tolerance and pluralism to their students. The teaching materials contained in the Aqidah Akhlak course can support tolerance and pluralism education in universities. The latest findings reveal that teaching lecturers are also a major factor in the 


\section{Sitti Jamilah}

dissemination of knowledge about tolerance education (Sirozi \& Yenrizal, 2020). Teaching materials that are in accordance with the context of tolerance education are able to contribute to religious tolerance education (Ifechukwude \& Gibson, 2021; Alhashmi et al., 2020). This is to support efforts to transform awareness towards an attitude of tolerance intensively and massively in the era of globalization. Teaching materials must be designed as well as possible in order to be able to provide understanding to students about the importance of respecting diversity and avoiding intolerance. Because in education, pluralism is understood as an attitude of respect for beliefs, ethnic and cultural diversity, and accepting the uniqueness of other people's views of life.

\section{Religious Intolerance and Pluralism According to an Islamic Perspective}

The second finding reveals Islamic views on religious intolerance and pluralism. The findings explain that in essence Muslims can accept a pluralistic society (pluralism) on the basis of mutual respect to create peace, but not to make it a religious ideology because each religion has different principles and beliefs so they cannot be equated. Thus, if you follow the guidelines of Islamic teachings, you seem to be neutral towards pluralism and do not recommend being intolerant because it can divide the unity and integrity of mankind. God created humans religiously, and diversity is not meant to destroy each other, but to be able to understand and respect each other. In Islam, religious intolerance is an act of denying the right of people of other religions to practice their beliefs freely. Therefore, it is highly recommended to be tasamuh or tolerant (Yanti \& Witro, 2019). The study states that the Prophet Muhammad SAW has practically demonstrated the formation of a pluralistic society consisting of a Muslim majority and a non-Muslim Jewish minority in Medina which was peaceful after his hijrah from Mecca in 622 AD. The Ummah was successfully formed by obedience to the Qur'an which was complemented by a constitutional and legal framework made by agreement. Pluralism has been created without violence or wealth, but because a pluralistic society holds Islamic principles, namely tolerance, social justice, and belief in God Almighty (Shiekh, 2013).

The formation of community pluralism in the era of Rasulullah is very relevant to the era of globalization, especially in universities where learning about pluralism and tolerance can be entered through teaching materials. In the era of globalization, people can connect very easily through information and communication technology (ICT). Mutual respect and appreciation for other religious beliefs is the main tool for reconstructing a global pluralistic society. Pluralism in Islamic teachings is described as various religious or cultural groups living together or living side by side in peace. Islam does not believe in the idea of different nationalities (asbiyah) based on race, ancestry, culture, and so on (Dobbins et al., 2021). Pluralism is seen as a fact that people are allowed to live side by side in harmony and peace in the same environment. According to Thoha (2009), Pluralism is a form of an institution that is more than moral tolerance in which there is diversity in gaining acceptance from the community or the surrounding environment. The opposite of intolerance, tolerance is a behavior that is recommended in Islam because it can create an absence of religious social conflict. In contrast to religious pluralism which emphasizes the 
understanding that religion is the same, this understanding is opposed by some Muslim scholars. So that religious pluralism is prohibited because it is feared that it will have a negative impact on the aqidah of Muslims. Islam declares itself as a religion that teaches about the importance of tolerance and is open to differences and pluralism (Alotaibi, 2021). In the Qur'an, there are several verses that explain matters relating to pluralism.

"Q.S ar Rum which means, And among the signs of His power is the creation of the heavens and the earth and your different languages and the color of your skin. Verily in that, there are indeed signs for those who know. Then in Q.S al Hujarat verse 13 which means, $\mathrm{O}$ mankind, indeed we created you from a male and a female and made you into nations and tribes so that you may know each other. Verily, the most honorable of you in the sight of Allah is the most pious among you. Verily, Allah is All-Knowing, All-Knowing. From Q.S ar Rum and al Hujurat, it can be understood that Allah created various kinds of human beings to know each other. Surely Allah has secrets and plans of his own to make humans like that."

Nazaruddin Umar's view is that pluralism is a natural law (Zuhri, 2018). He explained that in Q.S al Hud verse 118 there is the sentence wa law sya'a rabbuka laja'alannaasa ummatan wahidah which means that it is impossible for humans to be uniform. Therefore, humans live in various kinds of diversity, both gender, ethnicity, and nation, so they are called derivatives of necessity (Islam, 2020). Likewise, religious intolerance is not recommended in Islam. Islam teaches that there is no compulsion in religious matters as contained in Q.S al Baqarah verse 256.

Pluralism requires a serious approach, mutual understanding, and cooperation as well as well-organized and even legal measures to provide protection for society. Within the scope of higher education, it means that all academics and students must have the right to develop their respective identities and interests in accordance with applicable regulations so that there are no deviations. Each party must enjoy the equality of human rights and obligations as members of society (Shiekh, 2013).

The Qur'an has provided the necessary guidelines for realizing a truly plural or multicultural society. The relationship between Islam and pluralism actually rests on the spirit of humanity and universalism where Islam is a religion of humanity (fitrah) (Ridwan, 2020). From this statement, the researcher shows the novelty of the research from his previous studies by linking the Islamic view of intolerance and pluralism with universities in the era of globalization. Sources of Islamic teachings provide general principles on how to live for the people both in creating peace, stability, and social justice. Thus, as long as the IAIN Pare-Pare College evaluates teaching materials with regard to the sources of Islamic teachings, the impact of intolerance and pluralism can be avoided.

\section{E. Conclusion}

Based on observations of the literature study, the study revealed two findings. First, the competency standards and basic competencies of the Aqidah Akhlak course contain learning values about avoiding intolerance and supporting pluralism. Thus, these teaching materials contribute to preventing religious intolerance and provide a new perspective on 


\section{Sitti Jamilah}

pluralism. Second, in the view of Islam, it is known that religious intolerance is not recommended in Islam because this attitude can damage the integrity and personality of moral character. While pluralism there are two opposing schools between those who accept and reject. The relationship between Islam and pluralism actually rests on the spirit of humanity and universalism where Islam is a religion that respects human values. With the existence of teaching materials in certain subjects at universities, it is hoped that it will prevent the development of intolerance and pluralism among students. The values of pluralism are also able to foster mutual respect and respect between fellow human beings so that they can support the development of student morality. The expected implication is that universities must supervise and provide input on teaching materials that have the potential for the concepts of tolerance and pluralism. The government needs to support the socialization of the true importance of tolerance and pluralism in the campus environment.

\section{BIBLIOGRAPHY}

Alhashmi, M., Bakali, N., \& Baroud, R. (2020). Tolerance in UAE Islamic education textbooks. Religions, 11(8), 1-13. https://doi.org/10.3390/rel11080377

Allwright, R. L. (1981). What do we need teaching materials for? English Language Teaching Journal, 36(October), 5-18.

Alotaibi, H. H. S. (2021). A glimpse of tolerance in Islam within the context of al-dhimmah people (Egypt and Baghdad model). Journal of Islamic Thought and Civilization, 11(1), 99-111. https://doi.org/10.32350/JITC.111.06

Badru, O. R. (2020). (2020). Pluralism and African conflict: Towards a Yoruba theory of African political ethics of neighbourliness. In The Palgrave Handbook of African Social Ethics (pp. 167-183). Palgrave Macmillan, Cham.

Barras, A. (2013). Sacred Laïcité and the Politics of Religious Resurgence in France: Whither Religious Pluralism? Mediterranean Politics, 18(2), 276-293. https://doi.org/10.1080/13629395.2013.799345

Barton, G., Yilmaz, I., \& Morieson, N. (2021). Authoritarianism, Democracy, Islamic Movements and Contestations of Islamic Religious Ideas in Indonesia. Religions, 12(8), 641. MDPI AG. Retrieved from http://dx.doi.org/10.3390/rel12080641

Basya, M.H. (2011). The concept of religious pluralism in Indonesia: A study of the MUI's fatwa and the debate among Muslim scholars. Indonesian Journal of Islam and Muslim Societies, 1(1), 69-93. https://doi.org/10.18326/ijims.v1i1.69-93

Cloonan, M., \& Fingeret, A. L. (2020). Developing teaching materials for learners in surgery. SURGERY, 167(4), 689-692. https://doi.org/10.1016/j.surg.2019.05.056

CNN Indonesia. (2021). Intoleransi Beragama di Jatim \& Jabar Diklaim Naik 2019-2020. CNN Indonesia. Retrieved from https://www.cnnindonesia.com/nasional/2021100418145820-703252/intoleransi-beragama-di-jatim-jabar-diklaim-naik-2019-2020. 
Diana L. Eck. (2006). What is pluralism? The Pluralism Project, Harvard University. Retrieved from http://www.pluralism.org/pages/pluralism/meanings

Dobbins, T., Hughes, E., \& Dundon, T. (2021). 'Zones of contention' in industrial relations: Framing pluralism as praxis. Journal of Industrial Relations, 63(2), 149-176. https://doi.org/10.1177/0022185620957700

Effendi, M. R. (2020). Mitigasi Intoleransi dan Radikalisme Beragama di Pondok Pesantren Melalui Pendekatan Pembelajaran Inklusif. Paedagogie: Jurnal Pendidikan Dan Studi Islam, 1(1), 54-77. https://doi.org/10.52593/pdg.01.1.05

Facal, G. (2020). Islamic Defenders Front Militia (Front Pembela Islam) and its Impact on Growing Religious Intolerance in Indonesia. TRaNS: Trans-Regional and -National Studies of Southeast Asia, 8(1), 7-20. https://doi.org/10.1017/trn.2018.15

Fosnacht, K., \& Broderick, C. (2020). Religious Intolerance on Campus: A Multi-Institution Study. Journal of College and Character, 21(4), 244-262. https://doi.org/10.1080/2194587x.2020.1822875

Gustiana Kambo, A. A. Y. (2021). Political Identity and Religious Prejudice in a PostConflict Society: A Case Study of Poso, Indonesia. Journal of Southwest Jiaotong University, 56(3), 26-36. https://doi.org/10.35741/issn.0258-2724.56.3.43

Harwood, N. (2005). What do we want EAP teaching materials for? Journal of English for Academic Purposes, 4(2), 149-161. https://doi.org/10.1016/j.jeap.2004.07.008

Hobolt, S. B., van der Brug, W., de Vreese, C. H., Boomgaarden, H. G., \& Hinrichsen, M. C. (2011). Religious intolerance and Euroscepticism. European Union Politics, 12(3), 359379. https://doi.org/10.1177/1465116511404620

Hudson, T. D., Rockenbach, A. N., \& Mayhew, M. J. (2021). Examining the Relationship Between College Students' Interworldview Friendships and Pluralism Orientation. Teachers College Record, 123(7), 1-36. https://doi.org/10.1177/016146812112300706

Ifechukwude, E. M., \& Gibson, E. I. (2021). Reformation of the Almajiri through Formal Education: A Pathway to Countering Religious Conflicts in Nigeria. International Journal of Religious and Cultural Practice, 6(1), 23-32.

Islam, M. H. (2020). Tolerance Limitation in Facing Religious Diversity Based on the Teaching of Islam. Nazhruna: Jurnal Pendidikan Islam, 3(1), 1-13. https://doi.org/10.31538/nzh.v3i1.483

Karpov, V., \& Lisovskaya, E. (2008). Religious intolerance among orthodox Christians and Muslims in Russia. Religion, State and Society, 36(4), 361-377. https://doi.org/10.1080/og637490802442975

Khan, T., Österman, K., \& Björkqvist, K. (2017). Severity and Reasons Behind Religious Intolerance in Pakistan: Perceptions of Sunnis, Shias, Ahmadis, and Christians. European Journal of Social Sciences Education and Research, 10(2), 193. https://doi.org/10.26417/ejser.v10i2.p193-202

Kruja, G., Zaimi, A., \& Gjana, F. (2021). The Challenges of Religious Education at Schools in Multi-religious Societies: The Case of Albania. In Religious Diversity at School: Educating for New Pluralistic Contexts. Springer International Publishing AG. 
Mahfud, C., Prasetyawati, N., Wahyuddin, W., Agustin, D. S. Y., \& Sukmawati, H. (2018). Religious Radicalism, Global Terrorism and Islamic Challenges in Contemporary Indonesia. Jurnal Humaniora, https://doi.org/10.12962/j24433527.v11i1.3550

McGrath, I. (2013). (2013). Teaching Materials and the Roles of EFL/ESL Teachers : Practice and Theory. A\&C Black.

Mietzner, M., \& Muhtadi, B. (2018). Explaining the 2016 Islamist Mobilisation in Indonesia: Religious Intolerance, Militant Groups and the Politics of Accommodation. Asian Studies Review, 42(3), 479-497. https://doi.org/10.1080/10357823.2018.1473335

Mitchell, P., \& Alexandrova, A. (2021). Well-Being and Pluralism. Journal of Happiness Studies, 22(6), 2411-2433. https://doi.org/10.1007/s10902-020-00323-8

Muhid, A. (2020). Religious tolerance among college students: How it's influenced by religious orientation and personality traits? HUMANITAS: Indonesian Psychological Journal, 17(1), 55. https://doi.org/10.26555/humanitas.v17i1.12222

Neo, J. L. (2020). Regulating Pluralism: Laws on Religious Harmony and Possibilities for Robust Pluralism in Singapore. Review of Faith and International Affairs, 18(3), 1-15. https://doi.org/10.1080/15570274.2020.1795414

Nussbaum, M. (2004). Religious Intolerance. Foreign Policy, 144(1), 44-45.

Ridwan, A. H. (2020). Fiqh Pluralism: Comprehensive Analysis of Nurkholish Madjid Ideas Regarding Hermeneutics. Journal of Southwest Jiaotong University, 55(1), 1-14.

Sebastian, L. C., \& Arifianto, A. R. (2020). TRaNS special section on Growing Religious Intolerance in Indonesia. TRaNS: Trans-Regional and -National Studies of Southeast Asia, 8(1), 1-5. https://doi.org/10.1017/trn.2020.1

Shiekh, S. A. (2013). Pluralism in Islam: nature and development. Insight Islamicus: An Annual Journal of Studies and Research in Islam, 13(13), 63-83.

Sirozi, M., \& Yenrizal. (2020). Preventing Religious Radicalism on College Students in the Islamic State Higher Education (PTKIN) Case Study of Islamic State University (UIN) in Indonesia. PalArch's Journal of Archaeology of Egypt/ Egyptology, 17(6), 7062-7084.

Snyder, H. (2019). Literature review as a research methodology: An overview and guidelines. Journal of Business Research, 104(March), 333-339. https://doi.org/10.1016/j.jbusres.2019.07.039

Suleman, M., Chief, P. P. P., Ali, A., Cm, S., Ghulam, A., Musharraf, G. P., Qadri, A. (2018). The rise of religious intolerance in the politics of Pakistan?, 3-5. Retrieved from http://blogs.Ise.ac.uk/southasia/2018/04/16/the-rise-of-religious-intolerance-in-thepolitics-of-pakistan/

Thoha, A. M. (2009). Objectivity and the Scientific Study of Religion. Intellectual Discourse, 17(1).

Weber, R. P. (1990). Basic Content Analysis Second Edition. Sage Publication, Inc.

Yanti, B. Z., \& Witro, D. (2019). Self Maturity and Tasamuh As a Resolution of Religious Conflicts. INTIZAR, 25(2), 87-94. 
Examining Teaching Materials in Higher Education

Zuhri, M. A. (2018). Alquran dan Toleransi di Indonesia: Sebuah Analisa Surat al-Bāqarah: 148. Journal of Qur'an and Hadith Studies, 7(2), 116-130. https://doi.org/10.15408/quhas.v7i2.13397 